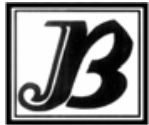

J. bio-sci. 19: 53-57, 2011

ISSN 1023-8654

http://www.banglajol.info/index.php/JBS/index

\title{
SHRIMP CULTURE PACKAGES IN SOUTHWESTERN BANGLADESH
}

\author{
D Sarkar, MAB Sayeed, GS Hossain, KA Huq* \\ Fisheries and Marine Resource Technology Discipline, Life Science School, \\ Khulna University, Khulna - 9208, Bangladesh
}

\section{Abstract}

Context: The study was conducted under the technical support of ATDP-II in Bagerhat District, from July to November 2005 on traditional, closed, and semi-intensive culture packages of penaeid shrimp (Penaeus monodon).

Objective: The objective of the study was to compare the management, technical and economic aspects of three different shrimp culture packages.

Materials and Methods: Post larval nursing was done for 30 days at a density of $50 \mathrm{PL} / \mathrm{m}^{2}$. Culture was done for 120 days at a density of $2.11,7.37 \& 11.56$ individuals $/ \mathrm{m}^{2}$ in traditional, closed, and semi-intensive ponds respectively. Shrimp PL were fed CP feed ( $40 \%$ protein) at a rate of $2 \mathrm{~kg}$ for $100,000 \mathrm{PL}$, but no supplementary feed was used in traditional ponds.

Results: The highest average daily growth $(0.263 \pm 0.026 \mathrm{~g} /$ day $)$ was found in traditional culture; while in closed, and semi-intensive system it was lower $(0.226 \pm 0.023$ and $0.239 \pm 0.022 \mathrm{~g} /$ day respectively) due to high stocking density and feed competition. Survival rates were found $49.14 \pm 5.94,57.94 \pm 8.01$ and $60.07 \pm 10.98 \%$ which yielded $327.23 \pm 24.14,1158.07 \pm 134.76,1991.57 \pm 232.70 \mathrm{~kg} / \mathrm{ha}$ in traditional, closed, and semi-intensive ponds respectively. Net income was calculated $47932.18 \mathrm{Tk} / \mathrm{ha}$ from traditional, $178779.2 \mathrm{Tk} / \mathrm{ha}$ from closed, and $312736.8 \mathrm{Tk} / \mathrm{ha}$ from semi-intensive culture.

Conclusion: The study suggests that instead of horizontal expansion of traditional shrimp cultivation, healthy management and improved culture technique are very much important to increase shrimp production in Bangladesh.

Keywords: Penaeus monodon, culture package, production, income.

\section{Introduction}

Coastal aquaculture in Bangladesh is mainly based on shrimp culture. Due to being a profitable business, the rapid commercialization of shrimp culture has occurred in the coastal areas of the country. Greater Khulna region is known as the main zone of shrimp cultivation and about $75 \%$ of country's shrimp production is obtained from these regions (Huq et al. 2004a).

According to Islam et al. (2005), most of the ghers are practiced in almost traditional ways, which is characterized by a large-sized gher (up to $100 \mathrm{ha}$ ), low stocking density, no feeding and fertilization, and poor management of water quality. As most farmers follow this extensive-traditional method, the average production of shrimp in our country is as low as $150-250 \mathrm{~kg} / \mathrm{ha}$, whereas in other countries, it reaches even $1,500-3,000 \mathrm{~kg} / \mathrm{ha}$ (FAO 1997). Better management practices have been advocated to improve this situation and to obtain a sustained production and profits (Wahab 2003).

Karim (2003) reported that mainly two types of shrimp culture systems, extensive-traditional and improvedtraditional, with different degrees of management are found in Bangladesh. Since different methods require different degrees of management, the production rates also differ remarkably with the method applied (Wahab et al. 2001). Now-a-days, trends are being changed and the farmers are aware of taking care about the culture of penaeid shrimp with some sustainable degrees of management initiatives. Despite the apparent economic success of shrimp farming, the question of sustainability has become a great issue in recent years as it contributes to the degradation of coastal environment and may threaten the sustainability of shrimp production (Islam et al. 2004). So, it is high time to implement sustainable shrimp culture techniques in Bangladesh.

\footnotetext{
*Corresponding author Email: hugka@yahoo.com
} 
Throughout the country, the government initiated a joint venture project (ATDP-II: Agro-Based Industries and Technology Development Project) with USAID to work for uplifting the status of different agricultural subsectors and a major part of this project was to promote the production of privately owned shrimp farms located in south-west part of the country that can succeed in an open competitive market environment. With an aim to notice the environmentally sound and economically beneficial shrimp culture method, this study was carried out in a number of commercial shrimp farms which run under the technical support of ATDP-II in Bagerhat District, the southwest coastal region of Bangladesh. The specific objective of the study was to compare the technical and economic aspects of different methods of shrimp culture, and to observe their feedback.

\section{Materials and Methods}

The experiment was conducted at a number of commercial shrimp farms run under the technical support of ATDP-II in Bagerhat district, located in the southwest region of Bangladesh. All the data regarding shrimp production from three different culture systems operated with different management regimes were collected fortnightly from the gher owners as well as ATDP-II extension workers from July to November 2005. Three ghers for each culture system were selected randomly. Modified traditional ghers were found to be characterized by large size (0.5-1.2 ha), whereas closed and semi-intensive ghers ranged from 0.2-0.45 ha and 0.32-0.42 ha respectively. Major differences in management of three culture systems and different steps of culture are discussed in the following sub-sections.

Two weeks before stocking, the ponds were thoroughly drained and sun dried. In the meantime, closed and semi-intensive ghers were enclosed with fine mesh nylon net to restrict the access of crabs, frogs, snakes or any other probable predators and disease carriers. All the three culture systems were treated with lime and fertilizer. Agricultural lime [dolomite; $\mathrm{CaMa}\left(\mathrm{CO}_{3}\right)_{2}$ ] was applied at the rate of $400 \mathrm{~kg} / \mathrm{ha}$. This was usually followed by fertilization (7-10 days after liming) with urea and TSP, applied at the rate of 20 and $7 \mathrm{~kg} / \mathrm{ha}$ respectively.

After a short break of 3-5 days subsequent to fertilization, the ghers were flooded with river water screening either through a micromesh or mosquito net to prevent entry of predators and other undesirable aquatic organisms, even their eggs or larvae. The screen was maintained at outlet also to prevent escape of fry. Unlike modified traditional system in which water exchange was based on pumping, every closed and semiintensive ghers had water reservoir, water supply (inlet \& outlet) and water treatment (bleaching - 600 kg/ha) amenities.

Subsequent to water supply single stocking was done in two types of culture system other than the modified traditional system. Hatchery-produced shrimp post larvae (PL) were nurtured at a density of $50 \mathrm{PL} / \mathrm{m}^{2}$ for 30 days in nursery ponds. Later on, the juveniles were shifted in pre-prepared grow-out ponds 7-8 days following the introduction of water, when the pond water had turned greenish and reared for 120 days at a density of 2.11, 7.37 and 11.56 individuals $/ \mathrm{m}^{2}$ in three respective systems of modified traditional, closed and semi-intensive culture. Prior to stocking in semi-intensive ghers, only PCR (Polymerase Chain Reaction) checked virus free PLs were taken and acclimatized to the water in the gher for about $30 \mathrm{~min}$ to suit in the new aquatic environment.

Nursery ponds in all types of culture system were treated with CP (Charoen Pokphand, Thailand) fine crumble feed with $40 \%$ protein level at a rate of $2 \mathrm{~kg}$ for $1,00,000 \mathrm{PL}$. Grow out ghers of modified traditional system were rarely treated with supplemental feeding. Shrimps in closed and semi-intensive culture were fed $\mathrm{CP}$ pellet feed with $38 \%$ protein level 6 times a day at $3.5 \%$ of their total body weight. Feeding rate varied according to the requirement and it was reduced to $2 \%$ of the total body weight as the shrimp gained weight after every successive days. 
In-culture Management: The physico-chemical parameters of the experimental ponds were monitored regularly by the ATDP-II extension workers. Closed and semi-intensive ghers were subsequently fertilized with chemical fertilizers on an irregular basis since the farmers did not follow the recommended doses of fertilization. Modified traditional ghers were replenished partially with new flood during the period of partial harvesting and re-stocking cycle; the water volume of other two systems was partially swapped over in each month throughout the culture period with treated water stored in reservoir. To minimize oxygen depletion due to high stocking density, aerator was used in semi-intensive ghers.

Data Analysis: Recorded hydrographic data and shrimp growth (weight) data were collected fortnightly from the gher owners as well as ATDP-Il extension workers. Data regarding the total number of shrimp harvested from each gher were also collected and the survival rates were determined in order to calculate the shrimp production in each gher. Finally all these data were assembled together and used for cost-benefit analysis.

\section{Results}

Growth, survival and per hectare yield of coastal shrimp raised under three different culture packages were determined successfully and the data are presented in Table 1. The mean final weights of shrimp found to be $31.56 \pm 2.67,27.12 \pm 2.64$, and $28.68 \pm 2.09 \mathrm{~g}$ with survival rates $49.14 \pm 5.94,57.94 \pm 8.01$ and $60.07 \pm$ $10.98 \%$ in modified traditional, closed and semi-intensive ghers respectively.

Table 1. Shrimp production performances in three different culture packages

\begin{tabular}{|c|c|c|c|c|c|c|}
\hline \multirow{2}{*}{ Parameter } & \multicolumn{2}{|c|}{ Modified traditional } & \multicolumn{2}{|c|}{ Closed } & \multicolumn{2}{|c|}{ Semi-intensive } \\
\hline & Range & Average* $^{*}$ & Range & Average* $^{*}$ & Range & Average* $^{*}$ \\
\hline Initial wt $(\mathrm{g})^{1}$ & $4.16-4.98$ & $4.52 \pm 0.31$ & $4.16-4.98$ & $4.52 \pm 0.31$ & $4.16-4.98$ & $4.52 \pm 0.31$ \\
\hline Final wt $(\mathrm{g})^{2}$ & $26.98-34.66$ & $31.56 \pm 2.67$ & $23.78-32.35$ & $27.12 \pm 2.64$ & $24.51-33.93$ & $28.68 \pm 2.09$ \\
\hline $\mathrm{ADG}^{3}$ (g/day) & $0.224-0.289$ & $0.263 \pm 0.026$ & $0.198-0.270$ & $0.226 \pm 0.023$ & $0.204-0.283$ & $0.239 \pm 0.022$ \\
\hline Survival (\%) & $38.40-55.35$ & $49.14 \pm 5.94$ & 45.53-66.37 & $57.94 \pm 8.01$ & $48.56-72.90$ & $60.07 \pm 10.98$ \\
\hline Yield (Kg/ha) & 279.74-359.38 & $327.23 \pm 24.14$ & $1015.44-1381.40$ & $1158.07 \pm 134.76$ & $1701.99-2356.13$ & $1991.57 \pm 232.70$ \\
\hline
\end{tabular}

${ }^{1}$ after 30 days, ${ }^{2}$ after 120 days, ${ }^{3}$ Average Daily Growth, ${ }^{*}$ Mean $\pm S D$

Table 2. Hydrographical parameters of the experimental ponds

\begin{tabular}{|c|c|c|c|c|}
\hline \multirow[b]{2}{*}{ Parameters } & \multicolumn{3}{|c|}{ Measured value } & \multirow{2}{*}{$\begin{array}{l}\text { Recommended } \\
\text { range }\end{array}$} \\
\hline & $\begin{array}{l}\text { Modified } \\
\text { traditional }\end{array}$ & $\begin{array}{l}\text { Closed } \\
\text { system }\end{array}$ & $\begin{array}{c}\text { Semi- } \\
\text { intensive }\end{array}$ & \\
\hline Temp. $\left({ }^{\circ} \mathrm{C}\right)$ & $25-34$ & $26-34$ & $25-33$ & $\begin{array}{l}\text { 22-32 (Ling 1969); 25- } \\
30 \text { (Boyd and Fast } \\
\text { 1992) }\end{array}$ \\
\hline Depth (m) & $0.5-1.2$ & $0.8-1.5$ & $1.2-1.5$ & $\begin{array}{l}1.0-1.5 \text { (Huq et al. } \\
2004 b)\end{array}$ \\
\hline $\mathrm{DO}(\mathrm{mg} / \mathrm{l})$ & $4-5$ & $4-5$ & $5-6.5$ & $\begin{array}{l}\text { 4.5-9.9 (George 1961); } \\
\text { 5.1-8.7 (Islam et al. } \\
\text { 1998) }\end{array}$ \\
\hline Transp. (cm) & $25-35$ & $24-33$ & $25-34$ & $\begin{array}{l}\text { 25-35 (Khandaker } \\
2003 \text { ) }\end{array}$ \\
\hline $\mathrm{pH}$ & $7.5-8.4$ & $7.6-8.5$ & $7.5-8.4$ & $\begin{array}{l}7-9 \text { (Boyd and Fast } \\
\text { 1992) }\end{array}$ \\
\hline Salinity (ppt) & $8-20$ & $10-20$ & $10-20$ & 15-25 ppt (Boyd 1989) \\
\hline
\end{tabular}

Table 3. Cost-benefit analysis of three different shrimp culture packages

\begin{tabular}{lrrr}
\hline Costs (Tk) & $\begin{array}{r}\text { Modified } \\
\text { traditional }\end{array}$ & Closed & $\begin{array}{c}\text { Semi- } \\
\text { intensive }\end{array}$ \\
\hline Gher prep. & 3000 & 5,000 & 7000 \\
Shrimp seed & 13500 & 36,000 & 67500 \\
Lime & 1750 & 3600 & 2800 \\
Fertilizer & 1000 & 1000 & 2400 \\
Feed & - & 99,000 & 270000 \\
Feeding trays & & 720 & 720 \\
Bleaching pow. & 1500 & 30000 & 30000 \\
Labour & 2500 & 5000 & 8000 \\
Farm manger & 8000 & 8000 & 16000 \\
Harvesting & 500 & 800 & 700 \\
Basket & 450 & 300 & 1000 \\
Spade & 320 & 320 & 320 \\
Transport & 800 & 500 & 500 \\
House repairing & 800 & 800 & 2000 \\
Others & 1000 & 1000 & 4000 \\
Total input & 62,450 & $2,22,040$ & $5,62,940$ \\
Gross income & 110382.18 & 400819.2 & 875676.80 \\
Net income & 47932.18 & 178779.2 & 312736.8 \\
Return invest.(\%) & 176.75 & 180.51 & 155.55 \\
\hline
\end{tabular}


The hydrographic parameters monitored regularly were within the culturable range (Table 2). Thus the variation in survival rates among three culture systems can be attributed due to different management schemes taken which ultimately resulted variation in shrimp production as well (Table 1). The total expenditure in each culture system was also affected by different degrees of management. Gher preparation, feeding, and fertilization costs were higher in semi-intensive system. On the other hand, seed, labour, and harvesting costs were higher in modified traditional system. Costs of these items in closed system were patchy, but the total cost was more or less midway to the other two systems (Table 3).

According to the current market price of shrimp, economic returns were calculated separately for each culture type from the cost-benefit analysis (Table 3 ) which divulges an increase of gross income, net income, and return on investment with the increase of intensity in different culture methods.

\section{Discussion}

Three different shrimp culture packages were compared and the results indicate a visual difference on shrimp production and its financial return among those packages. Survival rate of the shrimps and yield $(\mathrm{kg} / \mathrm{ha})$ were higher in the semi-intensive culture compound to the other two systems.

Traditional farms were characterized according to Kungvankij et al. (1985) by low stocking densities (e.g. $5,000 / \mathrm{ha})$ and hence low yield (100-300 kg/ha/yr), irregular pond size and shape, relatively low technical management inputs as well as comparatively small investment. A gradual improvement of this status has penetrated over years into the present shrimp culture practices in Bangladesh and the farmers still could not escape out fully from the periphery of traditional way of culture they used to follow once upon a time. Now the time has changed and it has brought such technological approach through which much higher yield can be obtained from even a small pond. Islam et al. (2005) demonstrated average shrimp production $204.46 \pm 62.65,155.88 \pm 10.64$ and $83.47 \pm 48.53 \mathrm{~kg} / \mathrm{ha} / \mathrm{cycle}$ from small $(1-5 \mathrm{ha})$, medium (6-10 ha) and large (>10 ha) ghers respectively. Similarly highest average shrimp production $(1991.57 \pm 232.70 \mathrm{~kg} / \mathrm{ha}$ ) was obtained in 150 days from currently studied small sized (0.32-0.42 ha) semi-intensive ghers. They attributed this higher yield of shrimp in small ghers to large extent due to better management in these ghers which indicated more intensive approach over there. In the present experiment, such type of intensification through high input and care reduced mortality of shrimp in semi-intensive ghers, hence yielded higher production. Masud et al. (1997) reported $76 \%$ and $58 \%$ survival rate against the stocking density of 25 and $35 \mathrm{PL} / \mathrm{m}^{2}$ respectively. The current study showeed the highest survival rate $60.07 \pm 10.98 \%$ ) was recorded in semiintensive system with a gradual decrease in closed $(57.94 \pm 8.01 \%)$ and then in modified traditional $(49.14 \pm 5.94 \%)$ system. Although different stocking densities were decided for different culture packages depending upon past experience and practices, but the optimization of stocking density is important for the intensification of culture to minimize feeding competition, thus increasing survival rate and growth.

Nuruzzaman (1993) reported that the ghers (1-2.5 ha) those were managed well yielded $189 \mathrm{~kg} / \mathrm{ha}$ per year in Khulna district, $221 \mathrm{~kg} / \mathrm{ha}$ per year in Bagerhat district, and $126 \mathrm{~kg} / \mathrm{ha}$ per year in Cox's Bazar district, whereas large ill manageable ghers (>25ha) produced lower yield of $122,74,57 \mathrm{~kg} / \mathrm{ha}$ per year respectively. So this management variation in shrimp culture is the core responsible factor for its yield variation.

\section{Conclusion}

For uplifting the status and to promote the production of privately owned shrimp farms, the present study concludes that the farmers should be commercial and scientific enough to use farm inputs such as fertilizers and supplementary feeds throughout the culture period to shape the industry in a more profitable format and to succeed in an open competitive market environment. Instead of horizontal expansion of shrimp cultivation, 
healthy management and improved culture technique are very much important to increase shrimp production in Bangladesh. For this type of intensification in shrimp culture method, the farmers need adequate technical and management knowledge which should be supplied to them through proper guidelines.

\section{Acknowledgement}

This shrimp culture project was run by the economic support of ATDP-II under the technical help of World Fish Center. The authors are thankful to ATDP-II and World Fish Center authorities for providing information and necessary facilities during the study period. Appreciation also goes to the cooperative shrimp farmers of Bagerhat District, Bangladesh for their kind cooperation and providing information related to the study during samplings.

\section{References}

Boyd CE, Fast, AW. 1992. Pond monitoring and management. In: Marine Shrimp culture: Principles and Practices. AW Fast, LJ Lester (eds.). Elsevier Science Publishers.

Boyd CE. 1989. Water quality management and aeration in shrimp farming. Fisheries and Allied Aquaculture Departmental Series No. 2 , Aburn University, Albama. p. 67

FAO. 1997. Report on Marine Fishing Village Identification Survey in Bangladesh. UNDP Project Publication No. 2. Bangladesh Fisheries Development Corporation (BFDC), Dhaka.

George MG. 1961. Diurnal variaions in two shallow ponds in Delhi, India. Hydrobiol. 18(6), 265-273. http://dx.doi.org/10.1007/ BF00162227

Huq KA, Islam MS, Rahman MA. 2004a. Suitable species composition in the polyculture technique of Thai pangus (Pangasius hypophthalmus) with carps and prawn. Bangladesh J. Fish 27, 13- 17.

Huq KA, Islam MM, Ferdous KS. 2004b. Production performance of Macrobrachium rosenbergii (De man) in monoculture versus polyculture system. J. Bangladesh Agril. Univ. 2(1), 141-149.

Islam MS, Islam MA, Alam MS, Reshma BZ. 1998. Effects of shrimp framing on physico-chemical qualities of water in some medium saline areas in greater Khulna district. Bangladesh J. Fish. 21(1), 83-89.

Islam MS, Kamal AHM, Wahab MA, Dewan S. 2004. Water quality parameters of coastal shrimp farms from southeast regions of Bangladesh. Bangladsh J. fish. Res. 8(1), 53-60.

Islam MS, Milstein A, Wahab MA, Kamal AHM, Dewan S. 2005. Production and economic return of shrimp aquaculture in coastal ponds of different sizes and with different management regimes. Aquaculture International 13, 489-500. http://dx.doi.org/10.1007/ s10499-005-9000-7

Karim MR. 2003. Present status and strategies for future development of shrimp culture in Bangladesh. In: Environmental and Socioeconomic Impacts of Shrimp Farming in Bangladesh. M. A. Wahab (ed.). Technical Proceedings of BAU-NORAD Workshop (BRAC Centre, Dhaka, Bangladesh). Bangladesh Agricultural University, Mymensingh, Bangladesh. p. 101.

Khandaker HR. 2003. Culture and Management of Penaeid Shrimp (Bagda Chingrir Chash O Babosthapona - Published in Bengali) $\left(5^{\text {th }}\right.$ ed.). Department of Fisheries, Ministry of Fisheries and Livestock, Dhaka, Bangladesh, p. 23.

Kungvankij P, Tiro LB, Pudadera JrBJ, Potestas JrlO, Chua TE. 1985. An Improved Traditional Shrimp Culture Technique for Increasing Pond Yield. Technology Series No. 1. FAO Document Repository.

Ling SW. 1969. The general biology and development of Macrobrachium rosenbergii (De man) with carps in ponds. Bangadesh J. Fish. Res., 4(2): 127-134.

Masud SAKM, Ramatullah SM, Islam MA. 1997. Effect of stocking density on growth, survival and production of tiger shrimp (Penaeus monodon). Bangladesh J. Fish. Res. 20, 117-118.

Nuruzzaman AKM. 1993. Coastal Environment and Shrimp Cultivation. Bangladesh Agriculture Research Council (BARC), Dhaka.

Wahab MA, Bergheim A, Braaten B, Islam MS, Rahman MM. 2001. Observation on some of the environmental parameters of selected shrimp farms in Khulna, Bangladesh. Bangladesh J. Fish. Res. 5(1), 75-76.

Wahab MA. 2003. Environmental and socioeconomic impacts of shrimp farming in Bangladesh. Technical Proc. BAU-NORAD Workshop, 5 March 2002, BARK Center, Dhaka, Bangladesh. Bangladesh Agricultural University, Mymensingh, Bangladesh, 101 p. 